\title{
Factors Affecting the Households' Willingness-to-Pay for Wastewater Treatment in Agro-Food Processing Craft Villages, Nhue-Day River Basin, Vietnam
}

\author{
Tran Thi Thu Trang1*, Roberto F. Rañola Jr.², Nguyen Van Song1 \\ ${ }^{1}$ Department of Natural Resources and Environmental Economics, Faculty of Economics and Rural Development, \\ Vietnam National University of Agriculture, Hanoi, Vietnam \\ ${ }^{2}$ Department of Agricultural and Applied Economics, College of Economics and Management, University of the \\ Philippines Los Baños, Los Baños, Philippines \\ Email: *tranthutrang1712@gmail.com
}

How to cite this paper: Trang, T.T.T., Rañola Jr., R.F. and Song, N.V. (2019) Factors Affecting the Households' Willingnessto-Pay for Wastewater Treatment in AgroFood Processing Craft Villages, Nhue-Day River Basin, Vietnam. Journal of Environmental Protection, 10, 1119-1130. https://doi.org/10.4236/jep.2019.109066

Received: July 22, 2019

Accepted: September 2, 2019

Published: September 5, 2019

Copyright $\odot 2019$ by author(s) and Scientific Research Publishing Inc. This work is licensed under the Creative Commons Attribution International License (CC BY 4.0).

http://creativecommons.org/licenses/by/4.0/

(c) (i) Open Access

\begin{abstract}
Industrialization is a major strategy of Vietnam for the development of the countryside. One such program is the promotion of craft villages that have been successful in increasing income levels that are 5 times more than those villages mainly engaged in agricultural production. However, while such programs have brought prosperity to these villages, they have ignored the adverse effects on the environment brought about by the wastewaters from the processing plants. Would these households involved in agro-food processing be willing to pay for the establishment of a wastewater plant to address the environmental problems? What factors would influence their willingness to pay? The results of the study among the selected households in Nhue-Day River Basin, Vietnam involved in agro-processing showed that the major factors affecting their willingness to pay for the establishment of a wastewater treatment plant are their level of education, quantity of households' untreated wastewater, presence of young children who are more vulnerable to the adverse effects of pollution, experience of family members getting sick, households' awareness of benefits from treated wastewater, capacity to pay, access to credit and membership in craft village's Association. The study recommended that decisions on addressing environmental issues should be participatory to be able to take into consideration the socio-economic conditions of the stakeholders.
\end{abstract}

\section{Keywords}

Wastewater Treatment, Willingness-to-Pay, Craft Villages, 
Ordered Logit Model

\section{Introduction}

Worldwide water utilization is severely affected by a tremendous increase in population and industrialization [1] [2]. There are tremendous costs associated with deterioration of surface water quality [3] [4] and water portability [5] from agricultural pollution. Many water-scarce and developing countries still depend on untreated surface water as their basic source of domestic water supply [1] [6] and water reuse is the only affordable alternative [7]. Environmental quality and antipollution legislation are the most widely used interventions to control and reduce environmental pollution [8] [9]. Therefore, in most countries, environmental laws have been enacted by the governments and been enforced through their administrative structures [10] [11]. In Vietnam, several studies indicated that Vietnam's weak regulatory framework in environmental management and the poor performance of the state's environmental agency are among the reasons for failure to identify the underpinning causes of pollution [12].

The Nhue-Day River Basin covers an area of 7665 square kilometers with a capacity of 28.8 billion cubic meters of water per year that flows through 5 provinces: Hanoi, Ha Nam, Nam Dinh, Ninh Binh, and Hoa Binh. The major contributors to the wastewaters of Nhe-Day River Basin are crop and livestock production that account for $67 \%$, craft villages wastewater for $17 \%$, domestic wastewater for $16 \%$ and hospital wastewater for $0.4 \%$ of the total wastewater discharged [13]. In addition, some of the wastewater also comes from outside the villages, specifically from Hanoi (48.8\%), Ha Nam (15\%), Ninh Binh (14\%) and Hoa Binh (4.4\%).

The craft villages in Hanoi are the major sources of industrial wastewater, accounting for $76 \%$ of the total industrial wastewater of 5 Nhue-Day River Basin provinces. Currently, Hanoi has 1350 craft villages, of which 272 villages recognized as traditional craft villages by the Hanoi City People's Committee. These traditional craft industries of the capital city have been contributing significantly to the creation of jobs and enhancement of income for people. However, they have also been discharging large volumes of wastewater to Hanoi's rivers, with some of these villages located in the crowded city accounting for a relatively larger amount of wastewater. The more serious source of environmental pollution comes mainly from industries involved in metal recycling and processing of agricultural products, metal, textile, and stone sculptures [14].

Despite the gravity of the pollution problems arising from these rural industries [15], however, there are a few serious and effective programs launched to address these environmental problems [16] [17]. An obvious solution to the water pollution is the establishment of wastewater treatment plants in selected traditional agro-food processing villages in Nhue-Day River Basin, Vietnam that would partly be paid for by the households in the craft villages. The question, 
however, is whether these households would be willing to pay for the establishment of the treatment plant? What factors would influence their decisions to pay for wastewater treatment to address the problem of wastewater pollution? This is the major focus of this paper.

\section{Research Methodology}

\subsection{Study Areas}

The study was conducted in 2017 in three traditional agro-food processing villages in Duong Lieu, Tan Hoa and Phu Do communes from three districts: HoaiDuc, QuocOai and TuLiem of Hanoi city that are parts of the Nhue-Day River Basin. The major criteria for choosing these villages were: 1) They directly discharge untreated wastewater to the Nhue-Day River Basin, 2) They are typical agro-food processing craft villages in Hanoi city, 3) Quantity of wastewater in these villages are the largest among other areas, and 4) Only one wastewater treatment facility has been installed and operated since October 2016.

The CauNga wastewater treatment plant in Duong Lieu commune that was established in October 2016 has been operating at $10 \$$ of plant capacity of only 2000 cubic meters a day. This is about $20 \%$ of the total amount of wastewater effluents generated from the agro-food processing plants. The rest of the untreated wastewater effluents are simply discharged directly to the common wastewater collection system before being released to the Nhue River. The untreated wastewater released into the river eventually pollutes the water wells that are the main sources of drinking water among most of the households in the commune. Duong Lieu in fact is considered one of the most polluted villages and also the first main point source of wastewater of the Nhue-Day River Basin [18].

In Hanoi city, the Phu Do village is very popular for its fresh noodles. The village covers a total area of 239 hectares with a total population of 13,856 people. There are 165 households in this village producing 50 tons of fresh white noodles daily that accounts for 50 per cent of the supply of the Hanoi market [19]. The daily total wastewater discharge per day of this village is about $300 \mathrm{cu}-$ bic meters [20], with the untreated wastewater from fresh white noodle production discharged to the common collection system that eventually ends up in the Nhue River. It was also reported by the Ministry of Natural Resource and Environment in 2014 that the BOD, nitrogen and phosphorus levels are three to four times higher than the standard level that suggests the water is seriously polluted.

Tan Hoa commune is well known for its tofu and dried vermicelli. This commune however discharges 200 tons of waste from the 70 households producing about 500 tons of dried vermicelli and 15 households producing about 0.3 tons of tofu per day [21]. All these wastes from the vermicelli and tofu production are discharged to the common collection systems that eventually end up in the Day River. The wastewater indices from the resulting water pollution show that they are very much higher than the accepted standard levels, even a hundred times more. It is therefore necessary to invest in renovation of the waste- 
water collection systems and improvement of efficiency of CauNga wastewater treatment plant to be able to treat a large volume of wastewater.

\subsection{Econometric Model}

There are many factors that affect the households' willingness to pay an additional monthly environmental fee that will be used to set up and maintain a wastewater treatment plant. In this study, the factors considered included the relationship of respondent to household head, age, gender, and education level, total monthly quantity of untreated wastewater from household, number of young children that are more vulnerable to pollution related diseases, number of times that members got sick within the last 6 months, and the average monthly household income (Table 1).

The dependent variable was the additional amount that households were willing to pay for a wastewater treatment. This was measured in a four point scale as follows: 1): 50,000 VND; 2): 100,000 VND; 3): 130,000 VND; 4): 200,000 VND. In the ordered logit model, the error term $\left(\varepsilon_{i}\right)$ is assumed to be normally distributed and the latent variable $Y^{*}$ as continuous as shown in Equation (1) [22] [23] [24].

$$
Y_{i}^{*}=\sum_{K=1}^{K} \beta_{k} X_{k i}+\varepsilon_{i}=Z_{i}+\varepsilon_{i}
$$

However, for this case: $Y^{*}$ is a single latent measure of household heads' WTP for monthly additional environmental fee for wastewater treatment, and $X_{k}$ is a vector of factors that affect the households' WTP. The continuous latent variable $Y^{*}$ has various threshold points. The $Y^{*}$ cannot be measured and can

Table 1. Definition of variables in the empirical ordered logit model for households' decision on willingness-to-pay for wastewater treatment in Nhue-Day River Basin.

\begin{tabular}{|c|c|c|}
\hline Variable label & Definition & Measure \\
\hline \multicolumn{3}{|c|}{ Dependent Variable } \\
\hline $\mathrm{Y}^{*}$ & $\begin{array}{l}\mathrm{Y}^{*} \text { is a single latent measure of respondents' } \\
\text { WTP for monthly additional environmental fee } \\
\text { for wastewater treatment }\end{array}$ & $\begin{array}{c}1=50,000 \mathrm{VND} \\
2=100,000 \mathrm{VND} \\
3=130,000 \mathrm{VND} \\
4=200,000 \mathrm{VND}\end{array}$ \\
\hline \multicolumn{3}{|c|}{ Independent Variables } \\
\hline Relation & Relation to household head & $\begin{array}{c}1=\text { household head } \\
0=\text { otherwise }\end{array}$ \\
\hline Age & Age of respondent & Years \\
\hline Gender & Gender of respondent & $\begin{array}{c}1=\text { Male } \\
0=\text { Female }\end{array}$ \\
\hline Edu & Educational level of household head & Years of schooling \\
\hline Quan WW & Quantity of untreated wastewater & Cubic meters \\
\hline Childs & $\begin{array}{l}\text { Presence of children under } 16 \text { years old in the } \\
\text { household }\end{array}$ & $\begin{array}{l}1 \text { if household has at least } \\
\text { one child, } 0 \text { otherwise }\end{array}$ \\
\hline Number disease & Frequency of illness among household member & Number of times \\
\hline Loginc & Logarit average monthly household income & \\
\hline
\end{tabular}

Note: 1 US\$ $=22,700$ VND. 
only be determined once it crosses the thresholds and observed based on the categories of responses as shown in the Equation (2):

$$
Y_{i}=\left\{\begin{array}{l}
1 \text { if } Y^{*}<\kappa_{1}(50,000 \text { vnd }) \\
2 \text { if } \kappa_{1}<Y^{*}<\kappa_{2}(100,000 \text { vnd }) \\
3 \text { if } \kappa_{2}<Y^{*}<\kappa_{3}(130,000 \text { vnd }) \\
4 \text { if } Y^{*}>\kappa_{3}(200,000 \text { vnd })
\end{array}\right.
$$

Parameters $\beta$ or coefficients denote the influence of explanation variables on the dependent variable. The positive sign of $\beta$ implies a higher households' WTP for additional monthly fee for wastewater treatment as the value of the related variable increases. Given four categories, there are three cutoff terms to estimate the probability that $Y$ will take on a particular value. The formulas are:

$$
\begin{array}{rl}
P\left(Y_{i}=1\right)=1 & 1-\frac{\exp \left(Z_{i}-\kappa_{j}\right)}{1+\exp \left(Z_{i}-\kappa_{j}\right)}=\frac{1}{1+\exp \left(Z_{i}-\kappa_{1}\right)} \\
P\left(Y_{i}=2\right) & =\frac{\exp \left(Z_{i}-\kappa_{1}\right)}{1+\exp \left(Z_{i}-\kappa_{1}\right)}-\frac{\exp \left(Z_{i}-\kappa_{2}\right)}{1+\exp \left(Z_{i}-\kappa_{2}\right)} \\
& =\frac{1}{1+\exp \left(Z_{i}-\kappa_{2}\right)}-\frac{1}{1+\exp \left(Z_{i}-\kappa_{1}\right)} \\
P\left(Y_{i}=3\right) & =\frac{\exp \left(Z_{i}-\kappa_{2}\right)}{1+\exp \left(Z_{i}-\kappa_{2}\right)}-\frac{\exp \left(Z_{i}-\kappa_{3}\right)}{1+\exp \left(Z_{i}-\kappa_{3}\right)} \\
& =\frac{1}{1+\exp \left(Z_{i}-\kappa_{3}\right)}-\frac{1}{1+\exp \left(Z_{i}-\kappa_{2}\right)} \\
P\left(Y_{i}=4\right) & =1-\frac{1}{1+\exp \left(Z_{i}-\kappa_{3}\right)}=\frac{\exp \left(Z_{i}-\kappa_{3}\right)}{1+\exp \left(Z_{i}-\kappa_{3}\right)}
\end{array}
$$

The marginal effects of changes in response variables were obtained once coefficients of the ordered logit model were estimated as shown in these equations:

$$
\begin{gathered}
\frac{\partial p(Y=1 \mid X)}{\partial X}=\beta p_{1}\left(1-p_{1}\right) \\
\frac{\partial p(Y=2 \mid X)}{\partial X}=\beta\left[p_{2}\left(1-p_{2}\right)-p_{1}\left(1-p_{1}\right)\right] \\
\frac{\partial p(Y=3 \mid X)}{\partial X}=\beta\left[p_{3}\left(1-p_{3}\right)-p_{2}\left(1-p_{2}\right)\right] \\
\frac{\partial p(Y=4 \mid X)}{\partial X}=1-\beta p_{3}\left(1-p_{3}\right)
\end{gathered}
$$

\section{Results and Discussions}

\subsection{Statistical Descriptions}

From the total survey samples, 9 respondents provided protest responses, that is, refused to answer the Willingness-to-Pay question. Therefore, only 267 respon- 
dents fully completed the survey. An ordered logit model with four-point scale of dependent variable (50,000 VND; 100,000 VND; 130,000 VND; and 200,000 VND) was used in this study to analyze the factors affecting the households' WTP decision for the additional monthly environmental fee. The explanatory variables for the econometric model are age of respondents, educational level of respondents, monthly quantity of households untreated wastewater, presence of children under 16 years old in the households, Frequency of illness among household members, awareness by households of the benefits of having a wastewater treatment plant, households' access to credit facilities, memberships in Craft Village's Association, and logarit of average monthly households' income (Table 2).

The summary of the socio-demographic characteristics of respondents shows that the average age of respondents was 46 years old with 8 years of schooling. Their skills in traditional craft were handed down from their parents. About 55\% of the households had at least one child under 16 years old and 3 members who got sick within the last 6 months. The monthly income of the households was high (about 25 million VND or 2000 US dollar).

The volume of untreated wastewater from households and agro-food processing activity was 107.94 cubic meters per month. About $64.8 \%$ of respondents were aware of the benefits from wastewater treatment. This study hypothesized that educational level of respondent, quantity of untreated wastewater from households, presence of young children, Frequency of illness among household members, awareness of wastewater treatment benefits, households' access to credit facilities, households' memberships in craft villages' associations, and logarithm of average monthly households' income are positively related with the households' WTP for monthly additional environmental fee. However, the relationship of age of respondents with households' WTP could not be determined a priori.

The four bid levels (50,000 VND; 100,000 VND; 130,000 VND and 200,000 VND) that refer to the amounts that respondents are willing to pay as monthly additional environmental fee for wastewater treatment were determined during a focus group discussion. Table 3 shows the percentage of respondents' choosing each of the WTP levels. The most frequent bid level chosen by $97 \%$ or $33 \%$ of respondents was 50,000 VND per month. The least chosen was bid level 130,000 VND with $41 \%$ or $15 \%$ of the total respondents. This means that the higher the environment fee, the less likely that respondents would be willing to pay.

\subsection{Empirical Results}

The econometric software STATA 14 was used to estimate the ordered logit regression. A summary of the ordered logit regression results for the households' willingness-to-pay for wastewater treatment is shown in Table 4. The results based on the p-values (Prob $>$ chi-square $=0.0000$ ) show that except for variable age, all the other variables are significant at least at the $5 \%$ level. In addition, the 
Table 2. Description of independent variables.

\begin{tabular}{|c|c|c|c|}
\hline Independent variables & Mean & Std. Err & Description \\
\hline Age of respondent & 46.150 & 0.489 & Continuous \\
\hline $\begin{array}{l}\text { Educational attainment of } \\
\text { respondent }\end{array}$ & 8.064 & 0.131 & Continuous \\
\hline Quantity of untreated wastewater & 107.94 & 7.17 & Continuous \\
\hline Children under 16 years old & 0.55 & 0.031 & $\begin{array}{l}\text { Dummy, } 1 \text { if household has at least one } \\
\text { child under } 16 \text { years old, } 0 \text { otherwise }\end{array}$ \\
\hline Frequency of illness among members & 2.99 & 0.148 & Continuous \\
\hline $\begin{array}{l}\text { Awareness of wastewater } \\
\text { treatment benefits }\end{array}$ & 0.648 & 0.029 & Dummy, 1 if aware and 0 otherwise \\
\hline Access to credit facilities & 0.59 & 0.03 & Dummy, 1 if access and 0 otherwise \\
\hline $\begin{array}{c}\text { Membership in Craft Village's } \\
\text { Association }\end{array}$ & 0.74 & 0.027 & Dummy, 1 if member and 0 otherwise \\
\hline $\begin{array}{l}\text { Logarit of average monthly } \\
\text { household income }\end{array}$ & 1.391 & 0.020 & Continuous \\
\hline
\end{tabular}

Table 3. Respondents' choosing WTP levels.

\begin{tabular}{ccc}
\hline WTP levels & Frequency $(\mathrm{n}=267)$ & Percent $(\%)$ \\
\hline 50,000 VND & 97 & 36.33 \\
100,000 VND & 84 & 31.46 \\
130,000 VND & 41 & 15.36 \\
200,000 VND & 72 & 26.85 \\
\hline
\end{tabular}

Note: 1 US\$ $=22,700$ VND.

Table 4. Estimated parameters of ordered logit model for households' decision in WTP for wastewater treatment.

\begin{tabular}{cccc}
\hline Independent Variables & Coefficient & Standard Error & p-value \\
\hline Age & 0.014 & 0.016 & 0.363 \\
Education & $0.136^{* *}$ & 0.061 & 0.027 \\
QuanWW & $0.005^{* * *}$ & 0.001 & 0.000 \\
Childs & $0.518^{* *}$ & 0.239 & 0.030 \\
Numberdisease & $0.148^{* * *}$ & 0.050 & 0.003 \\
Aware & $0.862^{* * *}$ & 0.274 & 0.002 \\
Accredit & $0.844^{* * *}$ & 0.253 & 0.001 \\
Memgroup & $0.720^{* *}$ & 0.290 & 0.013 \\
Loginc & $1.352^{* * *}$ & 0.413 & 0.001 \\
LR chi-square & 103.80 & & \\
Pro $>$ chi-square & 0.000 & & \\
Pseudo-R & 0.1473 & &
\end{tabular}

Note: ${ }^{*}$ significant at $10 \%,{ }^{* *}$ significant at $5 \%,{ }^{* * *}$ significant at $1 \%$. 
value of McFadden $\mathrm{R}^{2}$ (pseudo $\mathrm{R}^{2}$ ) at 0.1473 means that the explanatory variables in ordered logit model are able to explain $14.73 \%$ of the change in probability of the respondents' decision.

Although the estimated parameters of the ordered logit model provide only the direction of the impacts of independent variables on the dependent variable, the signs of the coefficients are important for interpreting the decision likelihoods. The marginal effect on the other hand shows the percentage change in the decision of the respondent with respect to WTP given a $1 \%$ change in the independent variable. The marginal effects computation of the ordered logit model in this study is shown in Table 4.

The results show that the amount that households would be willing-to-pay is positively associated with all explanatory variables at the $5 \%$ level of significance. In addition, all coefficients of explanatory variables are negative for the WTP level at 50,000 VND while at 100,000 VND WTP level there are no significant variables.

\section{- Educational level of respondents}

Educational level of respondents is statistically significant at $95 \%$ level of confidence. An additional year of schooling brings about $1.36 \%$ in probability of the household choosing 200,000 VND per month for wastewater treatment. This means that the more educated people are more aware of the risks to their health and environment from untreated wastewater compared to those with less education. They are more aware that it is cheaper to pay for wastewater treatment than paying for health treatment. That's why respondents are more likely to report a high level of willingness-to-pay for wastewater treatment as the level of formal education increases.

\section{- Quantity of households' untreated wastewater}

The quantity of untreated wastewater from households and agro-food processing activity discharged into the environment significantly affects at $1 \%$ level the WTP of households for wastewater treatment. Households who discharge high volumes of untreated wastewater are only $0.05 \%$ more likely to pay for wastewater treatment at WTP levels of 130,000 VND and 200,000 VND per month. This means that due to limited awareness of the adverse effects of pollution, only a few respondents are willing to pay more for treating wastewater. Without taking into consideration the effects of the other factors, the respondents are willing to pay only a fixed amount per month for wastewater treatment irrespective of the amount of wastewater discharged.

\section{- Presence of children under 16 years old}

The respondents who have young children or grandchildren in the households are more likely to be willing to pay for wastewater treatment given that they are more vulnerable to the health risks from pollution. About $5.13 \%$ of respondents are more likely to pay the $200,000 \mathrm{VND}$ per month for wastewater treatment.

\section{- Frequency of illness among household members}

The experience of households with members getting sick due to untreated wastewater affects their WTP for wastewater treatment. When considered, the 
payment for the wastewater treatment is much lower than the cost of hospital bills from medicines and doctor's services when family members get sick. The households who experienced sickness in the family due to the untreated wastewater are more likely to be willing to pay for wastewater treatment by 1.46 percent more. What this means is that the more times that members of the family get sick, the higher the willingness of household heads to pay for water quality improvement.

\section{- Households' awareness of treated wastewater benefits}

Respondents with greater awareness of the benefits of treated wastewater are more likely to report a high WTP level (200,000 VND per month) by $8.16 \%$. These benefits would include the reduction of health risks, restoration of the environmental conditions and others. Respondents who are aware of these benefits are more likely to be willing to pay the additional monthly additional environmental fee.

\section{- Households' income}

Income of a household is one of the most important factors affecting the households' decision on WTP for improved water quality and other households' activities. Income of households in research sites mainly come from activities relate to agro-food processing procedures. The respondents whose families have high income tend to pay more for the wastewater treatment. The results show that $29.51 \%$ of respondents were less likely to pay 50,000 VND per month for additional environmental fee while $13.37 \%$ of respondents were more likely to pay $130,000 \mathrm{VND}$ per month. About $13.40 \%$ of respondents were more likely to be willing to pay 200,000 VND per month for wastewater treatment. The average income of households in the study sites was much higher than the average Vietnamese household income and thus could be expected to have a higher demand for better environmental quality.

\section{- Access to credit}

In rural areas, credit institutions play an important role of providing households funds for investment. There are formal and informal credit institutions in the rural areas of Vietnam, namely the formal and informal. Pham and Izumida [25] mentioned that more than $30 \%$ of farmers in Vietnamdo not have access to formal credit institutions and are dependent on the informal credit providers that normally charge much higher interest rates. Hence, improved access to formal credit through microfinance programs is seen as a strategic tool to provide access to credit for the majority of poor households in rural areas [26]. In the study areas, capital is one of the most important inputs for agro-food processing of households. The results of the study showed that while $90 \%$ of the households have a need to borrow for their capital, only about $60 \%$ actually access the formal credit sources. The reasons for this are the lengthy bank procedures and limited budget for preferential interest rate. The results show that households who have access to credit are $18.68 \%$ less likely to pay 50 thousands VND per month while $8 \%$ of the households are more likely willing to pay an additional 200 thousand VND per month for the environmental fee. What this 
means is that households with access to formal credit are more likely to participate in the wastewater treatment program in order to improve the water quality.

\section{- Membership in craft village's Association}

Households who are members of Craft Village's Association are 6.79\% more likely to pay 130 thousands VND per month for wastewater treatment due to the benefits that these households gain from joining a craft association. The benefits from joining the Craft Villages' Association include access to market information, better prices for their products, consultancy services and legal representation in their business affairs.

\section{Conclusions and Recommendations}

The setting up of wastewater treatment plants is very critical for addressing the wastewater pollution generated by households involved in agro-processing given its associated impact on environmental quality and health risks. An important question is whether households would be willing to pay for the wastewater treatment plant and if so, how much? What important factors would influence their decision to pay for these wastewater plants? Results showed that households are willing to pay for setting up and maintaining the waste treatment plants. However, in setting up the rates, it is very important to take into consideration: their socio-economic conditions especially their level of awareness and knowledge of the direct effect of pollution on the health of their family as well as their capacity to pay given their level of income and access to sources of credit. The amount should also be commensurate with the volume of wastewater that they discharge.

As a matter of policy, it will be helpful if these households in agro-food processing craft villages will be provided more information about the adverse effects of pollution from the wastewater and the benefits from establishing wastewater treatment plants to mitigate its effects during village meetings. In addition, households can be encouraged to join the craft villages association to be able to enjoy the benefits from the support that these associations provide its members. These households should be provided with more access to formal lending institutions that would fund their investment requirements. This would require simplifying banking procedures to encourage these households to patronize these formal lending institutions. These types of changes should increase their income and enhance their willingness to pay for the wastewater treatment plant to improve water quality.

\section{Acknowledgements}

The author would like to give the sincerely thank to Southeast Asia Regional Center for Graduate Study and Research Agriculture (SEARCA) for providing me the financial support to conduct this research.

\section{Conflicts of Interest}

The authors declare no conflicts of interest regarding the publication of this paper. 


\section{References}

[1] Edokpayi, J.N., Odiyo, J.O. and Durowoju, O.S. (2017) Impact of Wastewater on Surface Water Quality in Developing Countries: A Case Study of South Africa. In: Tutu, H., Ed., Water Quality, InTechOpen, London, Chap. 18, 401-416. https://doi.org/10.5772/66561 http://www.intechopen.com/books/water-quality

[2] Mittal, R. (2013) Impact of Population Explosion on Environment. We School "Knowledge Builder" - The National Journal, 1, 1-5.

https://www.researchgate.net/publication/237771340_impact_of_population_explos ion_on_environment

[3] Szczykowska, J., Siemieniuk, A. and Wiater, J. (2015) Agricultural Pollution and Water Quality in Small Reservoir in Korycin. Journal of Ecological Engineering, 16, 141-146. https://doi.org/10.12911/22998993/599

[4] Lichtenberg, E. and Lessley, B. (1992) Water Quality, Cost-Sharing, and Technical Assistance: Perceptionsof Maryland Farmers. Journal of Soil and Water Conservation, 47, 260-263.

[5] Forster, D.L., Bardos, C.P. and Southgate, D.D. (1987) Soil Erosion and Water Treatment Costs. Journal of Soil and Water Conservation, 42, 349-352.

[6] Rasul, M.T. and Jahan, M.S. (2010) Quality of Ground and Surface Water of Rajshahi City Area for Sustainable Drinking Water Source. Journal of Scientific Research, 2, 577-584. https://doi.org/10.3329/jsr.v2i3.4093

[7] Saldias, C., Speelman, S., Huylenbroeck, G.V. and Vink, N. (2016) Understanding Farmers' Preferences for Wastewater Reuse Frameworks in Agricultural Irrigation: Lessons from a Choice Experiment in the Western Cape, South Africa. http://www.wrc.org.za

[8] Agrwal, V.K. (2005) Environmental Laws in India: Challenges for Enforcement. Bulletin of the National Institute of Ecology, 15, 227-238.

[9] Singh, K. (2014) Legislation: Environmental Law Regime in the United Arab Emirates: An Investor's Guide to Environment Compliance in the Construction Industry. Electronic Journal of Islamic and Middle Eastern Law, 2, 83-91.

[10] Faure, M.G. (1995) Enforcement Issues for Environmental Legislation in Developing Countries.

http://archive.unu.edu/hq/library/Collection/PDF_files/INTECH/INTECHwp19.pdf

[11] UNEP (2014) Enforcement of Environmental Law: Good Practices from Africa, Central Asia, ASEAN Countries and China. Expert Meeting on Enforcement of Environmental Law, Beijing, 19-22 May 2014, and a Peer Review Meeting, Nairobi, 13-14 August 2014.

https://wedocs.unep.org/bitstream/handle/20.500.11822/9968/enforcement-nviron mental-laws.pdf?sequence $=1$ \&isAllowed $=y$

[12] Dang, D.T., Sango, M. and Nguyen, T.V. (2010) Vietnam's Craft Villages and Water Pollution: A Review of Previous Research. Working Paper for the Project Crafting Sustainability: Addressing Water Pollution from Vietnam's Craft Villages. Supported by a Grant from the Australian Development Research Awards Scheme of AusAID.

[13] NDRBEPC (2014) Evaluation Report on Implementation of the General Project to Protect the Environment of Nhue-Day River Basin for the Period 2013-2014.

[14] Ministry of Natural Resource and Environment (MONRE) (2008) Vietnam National State of Environment Report: Vietnam Craft Village Environment. 
[15] Nair, I. (2014) Challenges of Rural Development and Opportunities for Providing Sustainable Livelihood. International Journal of Research in Applied, Natural and Social Sciences, 2, 111-118.

[16] Pauw, J.B., Gericke, N., Daniel Olsson, D. and Berglund, T. (2015) The Effectiveness of Education for Sustainable Development. Sustainability, 7, 15693-15717. https://doi.org/10.3390/su71115693

[17] Guevarra, D.M. and Florece, L.M. (2014) Factors Constraining the Natural Regeneration of Alibangbang (Bauhinia malabarica Roxb.). Journal of Environmental Science and Management, 17, 38-47.

[18] Duong Lieu (2017) Report on "Results of the Implementation of New Rural Community Standards". Duong Lieu Statistics Department.

[19] Phu Do (2016) Annual Report on "Results of the Implementation of the Socioeconomic Development Plan”. Phu Do Statistics Department, Hanoi City.

[20] Tran, T.H.G. (2013) Evaluate the Technology of Waste Water Treatment in Vermicelli Processing Village and Propose Solutions to Improve Processing Efficiency. Unpublished Master Thesis, Hanoi University of Natural Science, Hanoi.

[21] Tan Hoa (2016) Annual Report on "Results of the Implementation of the Socioeconomic Development Plan, Security-Defense 2016, Mission Orientation 2017”. Tan Hoa Statistic Department, Hanoi City.

[22] Williams, R. (2015) Ordered Logit Models-Overview. University of Notre Dame, Notre Dame. http://www3.nd.edu/ rwilliam

[23] Ndunda, E.N. and Mungatana, E.D. (2013) Farmers' Perception and Knowledge of Health Risks in Wastewater Irrigation. Open Science Repository Natural Resources and Conservation.

[24] Ndunda, E.N. and Mungatana, E.D. (2013) Determinants of Farmers' Choice of Innovative Risk-Reduction Interventions to Wastewater-Irrigated Agriculture. African Journal of Agricultural Research, 8, 119-128.

[25] Pham, B.D. and Izumida, Y. (2002) Rural Development Finance in Vietnam: A Micro-Econometric Analysis of Household Surveys. World Development, 30, 319-335. https://doi.org/10.1016/S0305-750X(01)00112-7

[26] Armendariz de Aghion, B. and Morduch, J. (2005) The Economics of Microfinance. MIT Press, Cambridge, 352 p. 